\title{
South Africa's E-toll System and the African Working Class Motorists: The Re-emergence of the Socio-Economic Exclusions of the Apartheid Urban Settlements
}

\author{
MS Tlou Ramoroka
}

\author{
Lecturer, Department of Development Planning and Management, University of Limpopo
}

Email: Millicent.Ramoroka@ul.ac.za

\author{
Doi:10.5901/mjss.2014.v5n15p49
}

\section{Abstract}

\begin{abstract}
This paper theoretically studies the effects of South Africa's e-toll system on the African working class mostly located in "urban" human settlements that are in the peripheries of cities in Gauteng Province. The e-toll system is a cost recovery strategy by the South African National Roads Agency Limited (SANRAL) to repay the loan that was taken to improve the roads (mostly freeways) for the 2010 Federation of International Football Association (FIFA) World Cup. In terms of transport infrastructure development, the National Development Plan (NDP) 2030 maintains that "the investments in the transport sector must bridge geographic distances affordability, foster reliable and safely so that all South Africans can access previously inaccessible economic opportunities, social spaces and services". However, South Africa's e-toll system undermines the aspirations of the NDP 2030 of building and promoting accessible towns and cities 20 years into the democratic dispensation. Apparently, the etoll system mostly affects the African working class motorists who are residing at the peripheries of the urban areas commonly in townships. These motorists are either faced with the daily charges of the e-tolls or have to use alternative congested and long routes in an attempt to access economic opportunities, social spaces and services in urban areas as compared to some wealthy fellow citizens who are housed in close proximity to the cities' centres. The Congress of South African Trade Union (COSATU) and other working class organizations held numerous protests before the launching of the e-toll system to demonstrate their concerns and lack of support towards the implementation and activation of the system. However, government ignored the concerns and aspirations put forward by mostly the African working class motorists and continued with the system as planned. Thus, the paper concludes that the e-toll system contributes to the re-emergence of the apartheid urban settlements by limiting the African working class motorists' accessibility to economic opportunities, social spaces and services that are available in urban areas.
\end{abstract}

Keywords: E-toll system; African working class; Socio-economic exclusions; Apartheid; Urban settlements

\section{Introduction}

Access to socio-economic infrastructure, services and spaces for people living in rural areas and townships far away from towns' and cities' centres is a key spatial development issue (Watson, 2009; Lucas, 2011; Velaga, Beecroft, Nelson, Corsar \& Edwards, 2012; Shedenova \& Beimisheva, 2013; Abou-Korin, 2014; Mattingly \& Morrissey, 2014). In most cases, accessibility to towns and cities by residents of rural areas and townships is determined by the distance they travel and the transport infrastructure and services that are connecting the areas (Lucas, 2011; Jones \& Lucas, 2012; Velaga et al., 2012). However, the integration of economic opportunities, social spaces and services and transport infrastructure must be at the centre when planning human settlements. Based on the past international spatial planning systems, there is a need to correct and improve the integration of economic opportunities, social spaces and services and transport infrastructure especially in the previously disadvantaged human settlements which mostly houses the poor (Lucas, 2011; Velaga et al., 2012; Abou-Korin, 2014; Mattingly \& Morrissey, 2014). Generally, different land-uses and transport infrastructure should be planned together in order to ensure that people are able to carry out their everyday activities easily. The integration of various land-uses means that people have the opportunity to extend their choices of jobs, retail facilities, leisure opportunities and also improve their residential amenities (Jones \& Lucas, 2012; Jou, Chiou, Kuo \& Tan, 2013; Abou-Korin, 2014; Mattingly \& Morrissey, 2014). Highly linked urban and rural settlements in terms of function, location, infrastructure and services have the ability to improve the socio-economic status of their societies (Velaga et al., 2012; Abou-Korin, 2014).

Contrary, South Africa's spatial planning, inefficient and expensive transport infrastructure limits and excludes the majority of the rural and township residents from fairly benefiting from socio-economic activities and services rendered mostly in and around urban centres. In Gauteng Province, the implementation of the e-toll system along the freeways 
adversely affects the African working class motorists who are commuting daily from townships to their work places mostly located in Pretoria and Johannesburg City centres and other nearby urban areas. These motorists are either faced with monthly e-toll bills of about R550 or have to use long and congested alternative routes in order to be able to access the socio-economic opportunities in urban areas. Apparently, South Africa's e-toll system undermines the aspirations of the NDP (National Development Plan) 2030 of building and promoting accessible towns and cities 20 years into the democratic dispensation. The e-toll system further operates against the efforts of poverty alleviation through transport infrastructure which is meant to spatially connect townships to towns' and cities' centres. It is against this background that this paper consists of five sections which include this introduction. The second section discusses the adoption of the e-toll system as a cost recovery strategy by most developed countries in order to cover the operational and maintenance costs of roads. The third section deliberates how South Africa's planned apartheid human settlements still perpetuate the socioeconomic exclusions which affects the majority of the Black populations. The fourth section demonstrates how the Gauteng Province's e-toll system revitalises and supports the emergence of the apartheid planned settlements 20 years into the democratic dispensation. The last section concludes that the e-toll system contributes to the re-emergence of the apartheid urban settlements by limiting the African working class motorists' accessibility to economic opportunities, social spaces and services that are available mostly in urban areas.

\section{The Adoption of the E-Toll System as a Cost Recovery Strategy}

Most international countries such as the Britain (Owens, 1995), Norway (leromonachou \& Warren, 2006), the United States of America (Kahn \& Roberds, 2009), Taiwan (Chiou, Jou, Kao \& Fu, 2013), Zimbabwe (Gideon \& Alouis, 2013), Portugal (Amorim, Lobo, Rodrigues \& Couto, 2014) and recently South Africa have adopted the electronic tolling (e-toll) system in addition to and some as a replacement of the manual toll collection system. For the first time, the manual tolling system emerged during the $4^{\text {th }}$ century in the first world countries with terms such as "toll way", "toll gates" and "road tolls" which were used interchangeably (Kahn \& Roberds, 2009; Gideon \& Alouis, 2013; Jou \& Haung, 2014; Yusuf, O'Connell \& Anuar, 2014). In most cases, this toll system is used as a strategy to recover the road construction, maintenance and operation costs in order to reduce the burden that was carried by the government (Amorim et al., 2014; Jou \& Haung, 2014; Yusuf et al., 2014). The road users are required to pay toll fees at certain points along the roads on passing. Additionally, the system can be used as an effective management strategy to address traffic demands and improve efficient use of roads especially the freeways (Chiou et al., 2013; Jou \& Haung, 2014; Noordegraaf, Annema \& van Wee, 2014; Yusuf et al., 2014). According to Amorim et al. (2014, p.881), freeways are "multilane, divided roads with full control of access and without traffic interruptions". These freeways often have toll charges that will assist in covering the building, operational and maintenance costs of the roads (Kahn \& Roberds, 2009; Chiou et al., 2013; Gideon \& Alouis, 2013; Amorim et al., 2014; Noordegraaf et al., 2014). As a response to the ever-increasing needs for improved infrastructure to support effective transportation, electronic technology had to be introduced (Gideon \& Alouis, 2013; Amorim et al., 2014; Jou \& Haung, 2014; Yusuf et al., 2014). Similarly to the manual tolling system, the e-toll system is common on freeways because of the high investment costs and level of services that the system requires (Kahn \& Roberds, 2009; Chiou et al., 2013; Gideon \& Alouis, 2013; Amorim et al., 2014; Jou \& Haung, 2014).

Apparently, the low costs and convenience in the collection of fees led to the implementation of the e-tolls in many countries (Owens, 1995; leromonachou \& Warren, 2006; Kahn \& Roberds, 2009; Jou et al., 2013; Noordegraaf et al., 2014; Jou \& Haung, 2014; Yusuf et al., 2014). In South Africa, a distance-based e-toll system driven by South African National Road Agency Limited (SANRAL) on behalf of the government was officially activated on December 3, 2013 on the Gauteng Province freeways. This e-toll system is adopted as a strategy to collect money from road users in order for the government to be able to repay the loan that was taken to improve Gauteng Province freeways mostly in preparation for the 2010 Federation of International Football Association (FIFA) World Cup. Additionally, through the system the fees collected will also be used to continuously improve and maintain the roads for sustainability and efficiency and also to cover for the operational costs, among other reasons. The international experiences suggest that the e-toll system that South Africa adopted does not require traffic to slow down or stop for fees collections therefore, saving time for the majority of the road users (Owens, 1995; leromonachou \& Warren, 2006; Kahn \& Roberds, 2009; Chiou et al., 2013; Gideon \& Alouis, 2013; Jou et al., 2013; Noordegraaf et al., 2014; Yusuf et al., 2014). Furthermore, this system reduces the high costs of building manual toll plazas and paying for the human resources involved in the operation and running of the plazas (Amorim et al., 2014; Noordegraaf et al., 2014; Yusuf et al., 2014). Instead, detection infrastructure known as electronic toll gantries are installed at certain areas and are used to collect information of all the vehicles passing underneath them for billing purposes. In order to realise the benefits associated with this e-toll system, all vehicles which will be using the freeways in Gauteng Province have to buy an on board unit known as an e-tag. These e-tags use a 
technological and location based service that charges fees only after the vehicle passed through the gantries which are erected every $10 \mathrm{~km}$ along the freeways (national roads and R21). The owners of vehicles that used the roads are sent an invoice which indicates all the gantries passed and the amount owed to SANRAL on a monthly basis. However, South Africa's e-toll system suggests that road users must pay for their social and economic costs influenced by their travelling and transport decisions. Thus, people's travelling decisions seem to have effects on development patterns, the routes, modes and duration of travel in and around their settlements (Owens, 1995; Mattingly \& Morrissey, 2014; Noordegraaf et al., 2014; Yusuf et al., 2014).

\section{Planned Urban Human Settlements and Socio-Economic Exclusions in South Africa}

South Africa's past apartheid urban planning system located the majority of Black human settlements far away from their work places, where services are difficult to sustain and where people experiences difficulties in an attempt to participate in social and economic activities (National Planning Commission (NPC), 2012; Walters, 2013). The nature of the apartheid human settlements resulted in limited accessibility, long travel distances and increased private motor car use between rural areas and townships and towns and cities (Mattingly \& Morrissey, 2014). Most often, people who reside in rural areas and townships are poorly served with transport infrastructure and services which are supposed to be connecting them to the inner towns and cities for socio-economic reasons and benefits. The routes linking the rural areas and townships with towns and cities are long as a result of the geographic locations of these areas which were promoted by the apartheid urban planning system (Christopher, 2004; Donaldson \& Kotze, 2006). These long routes make infrastructure maintenance difficult and movement of goods and people between the areas very costly. However, the post-apartheid urban planning system still promotes spatial segregation which mostly affects the low and working classes who are residing in townships and rural areas (Bond, 1999; Christopher, 2004; Donaldson \& Kotze, 2006; Lemanski, 2006; Lucas, 2011). Most of South Africa's rural areas and townships still experience development related challenges as a result of social exclusions, environmental unsustainability, economic inequalities, logistical bottlenecks, deteriorating infrastructure and the effects of new technologies, amongst others which affect the majority of the poor Black population (NPC, 2012).

According to the National Development Plan (NDP) 2030 "the major concentration of the poor should be spatially linked into the mainstream of towns' and cities' life through investments in transport infrastructure and the connecting corridors of development" (NPC, 2012: 285). In terms of transport infrastructure development, the NDP 2030 maintains that "the investments in the transport sector must bridge geographic distances affordability, foster reliable and safely so that all South Africans can access previously inaccessible economic opportunities, social spaces and services" (NPC, 2012, p.183). However, regardless of the high densities experienced in and around urban areas after 1994, the regeneration of inner urban areas and the growth of housing ownership and developments, little progress have been made in reversing the apartheid urban settlement planning. The NDP 2030 further confirmed that the relationship between where people live and how they make a living is often ignored. In changing the apartheid landscape, access to better transportation networks, services and infrastructure are very important in addressing the spatial transformation of urban areas (Bond, 1999; Christopher, 2004; Donaldson \& Kotze, 2006; Lemanski, 2006; Lucas, 2011). As such, the NDP 2030 directly responds to the Constitution of South Africa and the overarching principles for spatial development by putting in place strategies and initiatives that will ensure that all citizens live in healthy environments with access to adequate housing, basic services and economic and social activities and infrastructure (NPC, 2012). Thus, the unfair and unequal allocation of land, services and infrastructure between the rich and the poor clearly needs to be addressed in order to accommodate the needs of the previously disadvantaged groups by giving them fair and affordable access to economic opportunities, social activities, basic services and infrastructure.

\section{Effects of the E-Toll System on the African Working Class: The Re-Emergence of the Socio-Economic Exclusions of the Apartheid Urban Settlements}

Urban spatial development planning has in the past mostly served to exclude the poor from the economic, social and environmental benefits associated with towns and cities. However, with democracy it became possible to develop new planning approaches and systems which address urban growth and the major environment and resource issues which are pro-poor (Watson, 2009; Shedenova \& Beimisheva, 2013). The rationale of the introduction of the democratic spatial planning approaches and techniques was to ensure that the previously disadvantaged groups are integrated within the urban systems. Accordingly, urban spatial planning is one of the important tools of governance, through which the majority of issues related to urban development can be addressed. Watson (2009) asserted that protecting the needs of 
ordinary people rather than privileged minorities, the public rather than private interest, the future rather than the present through urban planning is very crucial especially in countries such as South Africa which were previously characterised by severe inequalities. Thus, spatial changes in urban areas are necessary to influence the location of recently developed human settlements and mixed land-uses, the complexity of transport systems and services provided in these areas in order to cater for the previously disadvantaged groups. In South Africa, the NDP 2030 affirms that "social and economic exclusions caused by the apartheid are still evident in the long distances many people, especially the poor, travel from where the live to where they work. Providing suitable means for the safe, efficient and cost-effective transport of people and goods is crucial. Such mobility broadens social and economic access, alleviating poverty" (NPC, 2012, p.184). Simultaneously, the same spatial changes can have adverse effects such as the fragmentation, separation, unequal spread of infrastructure and services and the labour market division which result in income inequalities (NPC, 2012; Velaga et al., 2012; Shedenova \& Beimisheva, 2013; Mattingly \& Morrissey, 2014).

In South Africa, the socio-economic exclusions caused by the transport systems and infrastructure are dominant between rural and urban areas and within urban areas. The introduction of the e-toll system on Gauteng Province's freeways adversely affects the majority of the African working class motorists who are residing at the peripheries of the cities specifically in townships. Most of these townships which include Soshanguve, Mamelodi, Mabopane, Atteridgeville, Alexandra, Soweto and Tembisa, amongst others are located at the peripheries of Johannesburg and Pretoria Cities. The geographic locations of these townships forces their residents to either use the toll roads or alternative long and congested roads in an attempt to access socio-economic activities and infrastructure mostly located in and around the cities' centres. Seemingly, the socio-economic exclusions that came with the apartheid planning are re-emerging within the urban areas as a result of the costs associated with the use of roads that in these areas. Although some people tried to reduce the limited accessibility of socio-economic opportunities and facilities in and around towns' and cities' centres by resorting to owning cars, their efforts are accompanied by a serious financial burden. In addition to paying the costs of owning cars such as monthly repayment instalments and the constantly increasing fuel prices, the e-toll has added more travel costs. The construction of the e-tolls gantries along the freeways reduces the ability of most African working class motorists to easily access the inner cities. There are about 49 gantries along Gauteng Province's freeways with an electronic detection to assist in the billing of motorists who uses the roads which the majority of those residing in townships have to pass on their way to and from the cities on a daily basis. The African working class motorists' economic status, their geographic locations and now the e-tolls provide them with limited access to their jobs and social infrastructure and other socio-economic activities which are mostly located in and around the inner cities. The spatial locations of most of the townships in Gauteng Province does not cater for pedestrians therefore, vehicles are needed to ensure that people are able to access the city centres. As a result, the African working class motorists who reside in townships must have at least R550 (or more if one does not have an e-tag) to pay for the e-toll bills on a monthly basis. Accordingly, these are the same people who are faced with challenges associated with unemployment growth, poverty, deteriorating living conditions and limited socio-economic infrastructure (Velaga et al., 2012; Shedenova \& Beimisheva, 2013; Abou-Korin, 2014; Mattingly \& Morrissey, 2014).

The current focus of South Africa's government is more on the improvement and the development of transport infrastructure which includes the building and upgrade of major roads connecting townships and rural areas to towns and cities (Bond, 1999; Lucas, 2011). However, these upgrades and developments which are initiated by the democratic government tent to ignore the mobility needs of the African working class motorists. The socio-economic, mobility and location related effects of the e-toll system on the African working class motorists were ignored during the initiation and planning stages of the system. As a result, the majority of people falling within the African working class are faced with transport poverty which is not only limited to high costs of travel but also includes the amount of time people spend on roads in an attempt to access economic and social facilities which are mostly in and around urban centres (Lucas, 2011; Velaga et al., 2012; Abou-Korin, 2014; Mattingly \& Morrissey, 2014). Furthermore, the long distances that are travelled by these people are associated with limited time to undertake other life supporting activities, discomforts and risks such as exposure to accidents, crime, noise and pollution that are experienced while travelling (Velaga et al., 2012; Shedenova \& Beimisheva, 2013; Abou-Korin, 2014; Mattingly \& Morrissey, 2014). In addition to these initial costs, discomforts and risks, the e-toll costs have been added to the daily burden of accessing city centres. Gauteng Province's e-toll system operates against the principles of poverty eradication and as such pushes some of the African working class motorists and their dependants back into their past poverty related status. In order to cover for the e-toll bills, the majority of the African working class motorists have to cut on money to buy food, electricity, water and even for paying rent (Lucas, 2011). If the African working class motorists cannot use alternative long and congested routes and are unable to pay for their monthly e-toll bills, then they will be unable to go to work and will loose their jobs. Thus, people who rely on these people for financial support will also suffer the socio-economic consequences which come with their providers' and 
supporters' job loses.

\section{Conclusion}

This paper argued that the implementation of the e-toll system along the Gauteng Province's freeways for cost recovery reasons mostly affects the African working class motorists who are townships' residents. These motorists currently have limited access to and use of roads which were meant to spatially bridge the gap between their townships, city centres and other urban areas. The African working class motorists are restricted from accessing the socio-economic opportunities and facilities mostly located in and around city centres as they cannot afford to pay the e-toll bills. Alternatively, these motorists have to spend more time on long and congested roads as an attempt to avoid the e-toll costs on freeways. Regardless of the efforts made by the Congress of South African Trade Union (COSATU) and other working class organizations to demonstrate and raise their concerns and lack of support towards the implementation of the e-toll system, the government ignored them and continued with the system as planned. As a result, the African working class motorists are either faced with the daily e-toll charges or spending more time on the long and congested roads in order to secure the socio-economic opportunities they have in and around city centres. In addition to the challenges associated with unemployment growth, poverty, deteriorating living conditions, financial constraints and limited socio-economic infrastructure, these people have to carry more financial burden which is brought by the e-toll system. Therefore, this paper concludes that the Gauteng Province e-toll system contributes to the re-emergence of the apartheid urban settlements by limiting the African working class motorists' access to economic opportunities, social spaces and services that are mostly available in and around urban centres.

\section{References}

Abou-Korin, A.A. (2014). Small-sized urban settlements: proposed approach for managing urban future in developing countries of increasing technological capabilities, the case of Egypt. Ain Shams Engineering Journal, http://dx.doi.org/ 10.1016/j.asej.2013.12.001.

Amorim, M., Lobo, A., Rodrigues, C. \& Couto, A. (2014). Optimal location of electronic toll gantries: the case of Portuguese freeway. Procedia: Social and Behavioral Sciences, 111, 880-889.

Bond, P. (1999). Basic infrastructure for socio-economic development, environmental protection and geographic desegregation: South Africa's unmet challenge. Geoforum, 30, 43-59.

Chiou, Y., Jou, R., Kao, C. \& Fu, C. (2013). The adoption behaviours of freeway electronic toll connection: a latent class modelling approach. Transportation Research Part E, 49, 266-280.

Christopher, A.J. (2004). Linguistic segregation in urban South Africa, 1996. Geoforum, 35, $145-156$.

Donaldson, R. \& Kotze, N. (2006). Residential desegregation dynamics in the South African city of Polokwane (Pietersburg). Tijdschrift voor Economische en Sociale Geografie, 97(5), 567-582.

Gideon, Z. \& Alouis, C. (2013). Mobilising domestic revenue through toll gates systems in Zimbabwe. International Journal of Business and Social Sciences, 4(7), 188-204.

leromonachou, P., Potter, S. \& Warren, J.P. (2006). Norway's urban tolling rings: evolving towards congestion charging? Transport Policy, 13, 367-378.

Jones, P. \& Lucas, K. (2012). The social consequences of transport decision-making: clarifying concepts, synthesising knowledge and assessing implications. Journal of Transport Geography, 21, 4-16.

Jou, R., Chiou, Y., Kuo, C. \& Tan, H. (2013). Freeways drivers' willingness to pay for an on board unit under an electronic toll collection system. Transportation Research Part C, 27, 16-24.

Jou, R. \& Huang, G. (2014). Willingness to pay price for tolls and on-board units for short- distance freeway users who normally avoid toll boots. Transport Policy, 31, 10-18.

Kahn, C.M. \& Roberds, W. (2009). Why pay? An introduction to payments economics. J. Finana. Intermediation, 18, 1-23.

Lemanski, C. (2006). The impact of residential desegregation on social integration: evidence from a South African neighbourhood. Geoforum, 37, 417-435.

Lucas, K. (2011). Making connections between transport disadvantage and the social exclusion of low income populations in Tshwane region of South Africa. Journal of Transport Geography, 19, 1320-1334.

Mattingly, K, \& Morrissey, J. (2014). Housing and transport expenditure: socio-spatial indicators of affordability in Auckland. Cities, 38, 69-83.

National Planning Commission (NPC). (2012). National Development Plan 2030: Our Future-Make it Work. Pretoria: The Presidency.

Noordegraaf, D.V., Annema, J.A. \& van Wee, B. (2014). Policy implementation lessons from six road pricing cases. Transport Research Part A, 59, 172-191. 
Owens, S. (1995). From 'predict and provide' to 'predict and prevent'?: pricing and planning in transport policy. Transport Policy, 2 (1), 43-49.

Shedenova, N. \& Beimisheva, A. (2013). Social and economic status of urban and rural households in Kazakhstan. Procedia: Social and Behavioral Sciences, 82, 585-591.

Velaga, N.R., Beecroft, M., Nelson, J.D. Corsar, D. \& Edwards, P. (2012). Transport poverty meets the digital divide: accessibility and connectivity in rural communities. Journal of Transport Geography, 21, 102-112.

Walters, J. (2013). Overview of public transport policy developments in South Africa. Research in Transportation Economics, 39, 34-45.

Watson, V. (2009). 'The planned city sweeps the poor away...': Urban planning and 21 st century urbanization. Progress in Planning, 72, 151-193.

Yusuf, J., O'Connell, L. \& Anuar, K.A. (2014). For whom the tunnel be tolled: a four-factor model for explaining willingness-to-pay tolls. Transport Research Part A, 59, 13-21. 